He published a fine volume on the "Hemiptera-Heteroptera of Holland," finally in a separate torm, but originally in the pages of the Tijdschrift voor Entomologie, the Transactions of the Dutch Entomological Society, of which he was the leading spirit. Through the same medium he offered a series of biological memoirs on the Dutch Saw-flies, probably unparalleled for completeness. He continued Sepp's "Beschrijvingen en Afbeeldingen van Nederlandsche Vlinders," which remains without an equal. And in the latter decade of his life he produced a remarkable work (now incomplete) on the Ichneumonidæ of North-Western Europe, under the title of "Pinacographia." No man was more universally esteemed when living; no man will be more thoroughly missed amongst entomologists. For Holland his loss appears to be irreparable.

In concluding this notice it should be remarked that all Van Vollenhoven's own works (and those of some other Dutch entomologists) were illustrated by beautiful and faithful drawings from his own pencil.

\section{A LEAF FROM THE HISTORY OF SWEDISH NATURAL SCIENCE ${ }^{1}$ \\ II.}

SCHEELE was born at Stralsund on the 9 th December, 1742 , the fifth in order of a numerous family. His father was a merchant of limited means who did not intend to give a learned education to his son Carl Wilhelm, who besides, like Linnæus and Berzelius, is said in his youth to have shown so little disposition for the common classical school studies that he was in danger of being considered the stupidest among his fellows. The Stralsund gymnasium accordingly was soon exchanged for the post of pupil to the apothecary Bauch at Gothenburg. Here Scheele was not kept very long at servile drudgery and mechanical hand labour; his attention to his duties and industrious reading of approved chemical authors soon gained him a place in the laboratory itself, where he not only distinguished himself by steady application and special skill in the accurate making-up of the preparations which belonged to the establishment, but also experimented in the silence of the night in order to satisfy his curiosity. He had now come to the right school bench, and with an experience led astray by no learned theories for his teacher, he laid the foundation of the chemical views and of that skill in chemical manipulation which were to gain for him so famous a name in the history of the natural sciences.

After the close of his six years' apprenticeship Scheele remained three years more at Gothenburg, afier which he was employed in an apothecary's shop at Malmoe. From Malmoe he removed three years after, in 1768 , to Stockholm. According to Wilcke's statement Scheele had by this time made several important discoveries, without however having succeeded in obtaining any direct acknowledgment of the accounts of the experiments relating to then which he had communicated to the Swedish Academy of Sciences. He was not, besides, satisfied with the employment he had obtained in the capital at the apothecary's shop, "Korpen," because he had nothing to do with the laboratory work proper. He therefore removed in 1770 to Upsala, attracted by the famous name of Bergman, to undertake the charge of the laboratory at one of the large apothecary's establishments there.

During his stay in Stockholm Scheele had given in to the Academy of Sciences several chemical papers which, after having been submitted to Bergman, were not printed, and it is even supposed that the learned professorof Upsala did not think it worth his while to read the productions of the young apothecary. At first, therefore, a certain coldness is said to have prevailed between these two men, of whom one was, and the other was soon to be, recognised

I Translated from a paper by Prcf. A. E. Nordenskjöld of Stockholm Continued from p. $52 \mathrm{I}$. as one of the greatest scientific geniuses of the century. An accident however soon brought them together, and the coolness gave place to a mutual friendship and admiration, of which the writings of both, and numerous letters from Scheele to Bergman, preserved in the Library at Upsala, bear witness. These pleasant relations exerted a great and fruitful influence on the scientific activity of both. The sharp-sighted experimenter and discoverer, Scheele, required the support of Bergman's regard and compre. hensive learning in order to win recognition, and Bergman's organising genius was brought by Scheele's discoveries in contact with new fields of research before untouched by any man of science.

While residing at Upsala Scheele published (1770-75) some of his most important researches, for instance, on fluor spar, on black oxide of manganese, on arsenious ac:d, on the composition of the air, \&c., and thus gained for himself almost at once a great reputation, not only in Sweden, but also in foreign countries. $\mathrm{He}$ was soon after chosen a member of the Swedish Acarlemy of Sciences, in whose circle he took his place on an equal footing with the first men of the realm. From this time the young chemist was honoured by this scientific association in a way that always will form one of its fairest memories, and which under similar circumstances could scarcely have happened to him so early in any other country,-a circumstance which shows that no credit is to be given to the story which has been repeated in several of the sketches of his life, that Scheele was so little known to the leading scientific men of Sweden that a distinction intended for him by Gustavus III. was by mistake conferred upon another person of the same name. On the other hand it may have been true, and if so, it showed the little interest that Gustavus III. and his court entertained for Swedish natural research, that the King of Sweden on the 2Ist March, 1784, while present at a meeting of the Turin Academy of Sciences, for the first time heard the name mentioned of the only person with a truly world-historical name who then lived in Sweden. Little also does he appear to bave suspected that in his own capital there was an Academy which, in respect of the influence it exerted on the progress of natural research, occupied a position quite equal to that of any other academy whatever.

From 1777 Scheele obtained from the Academy an annual grant of 100 rixdollars specie (about 40 guineas), to assi-t him in carrying on his chemical researches. He was present however at the meetings of the Academy only once, on the 29 th October, 1777 , when on his admission he read a paper " On a method of preparing Mercurius dulcis in the wet way." The day before he had undergone the apothecary's examination at the Medical College, and after taking the oath obtained an open commission empowering him, on the invitation of the magistrates, to be apothecary in the town of Köping.

For the longing for an independent sphere of activity had led Scheele in the autumn of 1775 to leave Upsala and remove to Köping, in order as dispenser to take charge of the apothecary's shop there, which belonged to a young childless widow of the former owner. From this time Scheele's life flowed calmly on in this town, uninterrupted by any remarkable occurrences, if we except a passing cloud caused by a buyer presenting himself with an offer to purchase the apothecary's shop of which Scheele had charge. This gave occasion to numerous proofs of friendship and regard for him. Gahn proposed that he should remove to his house ; Bergman offered him a place at his table till some other suitable employment should turn up. Linnæus, Wargentin. Bäck, Schultzenheim, Alströmer, and the brothers Bergius of fered him an apothecary's shop with a suitable laboratory and several advantages at Alingsos. Cithers wished to instal him as Chemicus regius in the capital and make him director of a new distillery. On D'Alembert's proposal 
he had been invited to Berlin and promised a salary of $I, 200$ rixdollars specie, and attempts were made to induce him to go to England by a promise of $£ 300$ a year, which foreign offers Scheele however declined, with the saying which indicates his modest requirements as to his mode of life, "I cannot do more than eat my meat ; if I can do that at Köping, I need not seek it elsewhere." He was soon freed from the trouble of choosing, by the townsmen of Köping and the gentry of the neighbourhood declaring that the town would not have any one else than Scheele as apothecary, and offering in case of need to obtain privileges and build a new apothecary's shop for him. The matter was thus settled to Scheele's advantage. He was allowed to retain his place as manager of the apothecary's shop at Köping till his death, which happened on the 2ist May, 1786, after some months' illness, probably brought on by constant work in cold laboratories with substances poisonous and injurious to health. Three days before his death he married the widow of the former apothecary, Fru Sonneman.

In the town house at Köping is preserved the inventory taken at the death of the great departed chemist. ${ }^{1}$ It gives us indeed an insight into the modest circumstances in which he lived, but it indicates economy and the possesion of some means, and shows that the glory of poverty, with which some biographers have sought to surround Scheele's memory, by no means corresponds with the actual facts. As indicating the scantiness of the literary assistance within Scheele's reach, it deserves to be noted that at his death, after a stay of more than ten years at Köping, he only possessed a collection of books consisting of twelve works on medicine and chemistry, with several other Swedish, German, and French books, valued at 6 spec. $(26 s$.)

Scheele was described as a man of moderate height and of a powerful frame. His modest manners and his genuine worth speedily won for him the friendship and affection of all with whom he came in contact. He appears to have prospered most at Köping, whose inhabitants entertained for him great regard, mingled with admiration at the experiments and researches, to which he devoted all the time he could spare. The memory of the distinguished man is still preserved in the town. There they tell you that the stone lion, which forms the sign of the apothecary's shop, had been gilt by Scheele so well as never to require renewal, that Scheele made a vane to the steeple, a sun, with rays pointing in many directions, which protects it from lightning without any lightning conductor; that Scheele tried to make gold, and with that end in view worked much with Spanish green, which brought about his death, \&c.2

When Scheele died he had not completed his fortyfourth year. A great part, perhaps the greater part, of his short life-path had been constantly occupied with earning a living, and for a complete exhibition of the influence he exerted it would not be enough to go leaf by leaf through the field of chemical research. We must also take note of the development of chemical physiology, of pharmacy, and above all of the whole of the industrial arts of recent origin, for on all these branches of human knowledge his genius has impressed an ineffaceable stamp. Here we can only give a short sketch of his most important discoveries.

Scheele's first work of which we have any knowledge, "Chemical Experiments with Sal Acetosellæ," was given in to the Swedish Academy on the 17th of August, 1768.

I The inventory shows:-Assets, gold and silver, 6r spec.; tin, to spec; glass and purcelain, II spec.; other movables, I8y spec.; apothecary's shop, 667 spec.; goods in apothecary's shop, 175 spec. ; real property, 500 spec.; open accounts, roo spec. : total I,7II spec. (about 376\%.). Against this sum there are indeed debts amounting to 630 spec., but if proper attention be given to the economical state of Sweden at that time, Scheele must have been considered by his contemporaries a man in confortable circumstances.

stances.
A story which probably originated from the manufacture of a large quantity of "Scheele's green."
It was read to the Academy, but not printed. Two years after we find for the first time Scheele's name in the Transactions of the Academy, in a paper by Anders Johan Retzius, in which he states that Scheele, a Pharmacie Studiosus, of good abilities and eager to learn, had succeeded in producing from tartar, by means of chalk and sulphuric acid, a clear and pure acid. To judge by the title and some remarks of Gahn's, it appears that the first-named work contained a fundamental discovery in organic chemistry, viz. that of oxalic acid. The discovery of tartaric acid formed a further important step forward within the same branch of knowledge, and was besides of epoch-making significance through the new method which Scheele here for the first time employed in producing the acid. The same method is still used in similar operations, and in Scheele's skilful hand formed the means by which he separated and ascertained the properties of a number of other organic acids occurring in animal and vegetable juices, as citric, malic, and lactic acids, all substances before unknown, or of whose true nature the knowledge was very obscure and erroneous. By other experiments and researches, which were always simple and went straight to the mark, Scheele enriched the chemistry of animals and plants with the discoveries of uric acid, gallic acid, and glycerine. It lies beyond the scope of this paper to give an account of the great importance of these discoveries, not only for theoretical chemistry, for medicine, and animal and vegetable physiology, but also in a purely technical point of view. Only as an instance, we give here some notes of the technical history of glycerine.

While engaged in some pharmaceutical work, Scheele found that by heating oils and animal fats with oxide of lead it is possible to extract from them an uncrystallisable substance with a sweet taste, which, like common sugar, when treated with nitric acid yields oxalic acid. On this account he named the new substance oil-sugar-a name afterwards changed to glycerine. As usual Scheele carefully ascertained the chemical properties of the new substance, yet without carrying out the research by investigating the nature of the ingredient of the fatty matter which combines with the oxide of lead. This was not done till about thirty years afterwards, when Scheele's research was resumed by Chevreul, who, starting from Scheele's observations, after twelve years' hard work, cleared up the true nature of the animal fats and showed that they contain, along with glycerine, various fatty acids which with alkalies form soap, and one of which, under the name of stearine, has since been extensively used as light-yielding material. It is on this research that the modern soap industry and the manufacture of stearine candles, \&c., are grounded. Glycerine, too long neglected as a useless by-product, has obtained a manifold practical application, not least in Sweden, where, as is well known, it now forms the raw material of one of our most important explosives, a main constituent of aseptine, \&c.

By these researches in a field of investigation in which Scheele had scarcely any predecessor, he was the true founder of our chemical knowledge regarding the productions of organic nature, for the further development of which hundreds of professorships have been established, and which has long since become of incalculable importance for the intellectual progress and economical advantage of the human race. This field of inquiry he further enriched by the examination of a number of ethers, and above all by his " Research on the Colouring Matter of Berlin Blue." A brief historical sketch may perhaps here also be of interest.

In the beginning of the eighteenth century Diesbach, a German dyer, along with the alchemist Dippel, ${ }^{1}$ accidentally discovered the beautiful blue colour which is known under the name of Berlin blue. The discovery, which supplied a

\footnotetext{
I German alchemist and mystic, died 1734 .
} 
long-felt want of a good and cheap blue colouring matter, was at first kept secret, till the process of preparation was published in a paper in the Philosophical Transactions, 1724 , by Woodward. Afterwards a number of chemists attempted to ascertain the true nature of the colouring matter, but without any further success than that improvements were made in the process of preparation, and some new substances were discovered, into the composition of which the colouring principle entered as a constituentamong which as the most important may be named the yellow prussiate of potash discovered by Macquer in 1752 . In 1772 Sage still believed that phosphoric acid entered as a constituent into the composition of prussiate of potash, and in 1786 Westrumb declared the colouring matter to consist of a volatile phosphor-soap. Two short papers by Scheele, together occupying not more that twenty-two pages of the Transactions of the Swedish Academy of Sciences for $I 782$ and $I 783$, at last brought clearness into this confusion. Scheele showed that the origin of the colouring power was a peculiar volatile acid (blue acid), whose properties he accurately ascertained, and of which he produced many new and important compounds. Scheele, besides, showed that the acid contained carbon and nitrogen, and that when subjected to combustion it gives off carbonic acid, and to dry distillation ammoniacal salts among others. On the other band, Scheele is thought not to have suspected that the substance which, without any special precautions, he produced in considerable quantity, smelled and tasted, forms one of the most powerful poisons with which we are acquainted. The work thus begun by Scheele was carried on by later chemists (Porret, Gay-Lussac, Berzelius, Faraday, Gmelin, Wöhler, Liebig, \&c.), and it is perhaps not too much to say that the accurate knowlodge we have thus obtained of the nature of the compounds of cyanogen has exerted an influence on the development of chemistry only inferior in importance to that of the discovery of oxygen and chlorine.

We find the first printed work of Scheele in the Transactions of the Swedish Academy of Sciences for $177 \mathrm{I}$. It bears the title, "On Fluor Spar and its Acid." Among the treasures which Pompey brought with him to Rome after his victory over Mithridates are enumerated goblets and cups of a beautifully-coloured fragile mineral, which, from the town at the plundering of which they were first obtained, were named Vasa myrrhina. They soon became fashionable, and Pliny and other writers speak of the fabulous sunis that were paid and the bloody deeds that were done in order to obtain them. Among all the different objects belonging to Ancient Rome preserved in our museums, there is not, remarkably enough, a single fragment of these vessels so renowned in the history of luxury but it has been guessed that they were made of a mineral which is now called fluor spar, and is still occasionally used for vases and cups. In mineralogical literature proper this mineral is first mentioned by the Saxon Agricola, who speaks of its use as a flux in the smelting of metals, and warns against mistaking this beautifully-coloured, but brittle and by no means hard mineral for a precious stone. Somewhat more than a century afterwards the art of etching on glass by means of this mineral was discovered at Nürnberg; and about the same time Elsholz, a Berlin physician who employed himself in the examination of phosphorescent substances, discovered that fluor spar became self-luminous when heated. All substances that are self-luminous without sensible combustion attracted at that period immense attention-certainly a survival from the alchemists' dreams about the philosopher's stone, which, among its other perfections, was also to have that of being self-luminous. The mineral, in consequence of its property of being a "light-bearer," now became the object of repeated but rather resultless examinations, until Scheele, by some simple experiments both analytic and synthetic, showed that the mysterious substance consisted of "lime saturated with a peculiar acid." This acid attacks glass and dissolves with ease siliceous substances. Scheele at first employed glass-vessels in producing it, which gave occasion to erroneous statements. The mistakes were immediately acknowledged and corrected when Scheele's attention was drawn to them by the apothecary Meyer of Stettin. Unwarranted objections, for instance by the Frenchman Boulanger, who declared that fluoric acid was nothing else than muriatic acid combined with some earth, and by Monnet, who believed that fluoric acid was only vitriolic acid "volatilised by means of a singular combination with fluor spar," were on the other hand refuted by new experiments in a paper printed in the Transactions of the Swedish Academy of Sciences for 1780. Scheele's examination of fluor spar had as its direct result the discovery of the simple substance fluorine, which without doubt, through its general occurrence in nature, and its properties differing from those of all other simple substances, is destined to play a very important part in the development of chemistry, although our knowledge of it is yet very incomplete from the impossibility of procuring vessels capable of resisting its corroding action.

( $T o$ be continued.)

\section{ON THE LONG PERIOD INEQUALITY IN
RAINFALL}

I. $\mathrm{F}$ it be true that there is a variation in the power of the sun depending on the state of his surface, this variation might naturally be expected to make itself apparent through a corresponding change in the rainfall of the earth, so that when the sun is most powerful there ought to be the greatest rainfall.

2. While the connection indicated above is that which most readily occurs to the mind, yet the difficulty of ascertaining the facts of the case in a manner bearing the smallest approach to completeness, is so great as to be at present insuperable.

There is, first of all, an intense reference to locality in rainfall, so that the rainfall at one place may differ greatly from that at another place in its near neighbourhood.

Again, there are, probably, in addition to possible secular inequalities, very great oscillations in the yearly rainfall at any one place, or accidental variations as we may term them, in our ignorance of their cause.

Thirdly, it is in comparatively few places, and those places chosen not with the smallest reference to this particular problem, that we have anything like a trustworthy account of the rainfall throughout a considerable number of years.

Fourthly, we have no information of any importance with respect to the rainfall at sea.

3. Besides the formidable catalogue of difficulties now mentioned, we ought to bear in mind the following considerations. The convection currents of the earth are regulated by two things, one of which is constant, while the other may be variable. The constant element is the velocity of rotation of the earth on its axis, while the element of possible variability is the power of the sun. Hence it follows that if the sun be variable. it will cause a variation in the direction as well as in the intensity of the earth's convection-currents on the principle which tells us that the resultant of two forces, one constant and the other variable, must vary both in magnitude and direction.

Now if it be true that we have a long period variation, not merely of the intensity, but also of the distribution of the earth's convection-currents, and if we bear in mind the intensely local reference in rainfall, it would be too much to expect that the rainfall inequality should exhibit the same years of maximum and minimum at all places.

${ }^{\mathbf{I}}$ By Balfour Stewart, LL.D., F.R.S., Professor of Natural Philosophy at the Owens College, Manchester. Being 2 paper read before the Lit. and Phil. Society of Manchester. 